\title{
Autoimmunity to $a$ myosin in a subset of patients with idiopathic dilated cardiomyopathy
}

Jonathan H Goldman, Philip J Keeling, Rahat S Warraich, Mizra K Baig, Simon R Redwood, Luciano Dalla Libera, John E Sanderson, Alida L P Caforio, William J McKenna

\begin{abstract}
Objective-To use an enzyme linked immunoassay (ELISA) technique to assess frequency and disease specificity of anti$a$-myosin antibodies in patients with dilated cardiomyopathy and their relatives.

Methods-Evaluation was performed on sera (dilution 1/320) from 123 consecutive patients with dilated cardiomyopathy (WHO criteria) (age 42 (SD 14) years), 252 of their relatives (35 (17) years), 203 healthy controls (45 (16) years), and 92 patients with ischaemic heart disease (63 (11) years).

Results-Abnormal antibody levels were commoner in patients with dilated cardiomyopathy $(25,20 \%)$ than in ischaemic heart disease $(4,4 \%)$, or normal controls $(4,2 \%, P=0.001)$. Forty one $(16 \%)$ of the relatives had abnormal results compared to the controls $(4,2 \%, P<0.001)$ and antibodies were detected in $20(38 \%)$ of pedigrees. Relatives from non-familial kindreds had higher antibody levels than those with familial disease $(P \ll 0 \cdot 001)$, and higher antibody levels were identified in 53 relatives of probands who had abnormal results compared to 116 relatives for whom the proband had a normal result $(0.37$ (SEM 0.02) $v \quad 0.22(0.01)$; $\mathbf{P}<0.001)$.

Conclusions-The finding of anti-amyosin antibodies in $20 \%$ of patients with dilated cardiomyopathy, in $16 \%$ of their asymptomatic relatives, and in $38 \%$ of families (particularly those with nonfamilial disease and where proband also had an abnormal result) provides additional evidence for autoimmunity against $a$ myosin in a subset of patients.
\end{abstract}

(Br Heart F 1995;74:598-603)

Keywords: anti-myosin antibodies; idiopathic dilated cardiomyopathy; cardiac specific antibodies; enzyme linked immunoassay

Dilated cardiomyopathy is a chronic heart muscle disease of unknown aetiology, characterised by a dilated and poorly contracting left ventricle. ${ }^{12}$ Familial disease is common $(25 \%)^{34}$ and there is increasing evidence for autoimmunity in a proportion of patients ${ }^{5-9}$ and in their asymptomatic relatives. ${ }^{10}$

The potential importance of autoimmunity against $a$ myosin has been emphasised by experimental models of murine myocarditis. ${ }^{11} 12$ Western blotting is only semiquantitative but has shown that cardiac antigens recognised by autoantibodies present in human dilated cardiomyopathy include both $a$ (heart specific, atrial) ${ }^{13}$ and $\beta$ (ventricular and slow skeletal) myosin, as well as other antigens. ${ }^{14} 15$

Previous reports of antimyosin antibodies detected by enzyme linked immunosorbent assay (ELISA) in patients with myocarditis ${ }^{16}$ and dilated cardiomyopathy ${ }^{17}$ used human ventricular $\beta$ myosin (non-heart-specific) or myosin of animal origin, rather than human $a$ myosin; moreover the frequency of antimyosin antibodies in relatives of patients with dilated cardiomyopathy has not been previously evaluated.

The aim of this study was to use a sensitive and specific ELISA to assess frequency, disease specificity, and level of anti- $\alpha$-myosin antibodies in patients with dilated cardiomyopathy and their relatives.

\section{Methods}

PATIENTS WITH DILATED CARDIOMYOPATHY One hundred and twenty three consecutive patients with dilated cardiomyopathy (mean age 42 (SD 14) years, 93 male, 30 female) presented to St George's Hospital between 1989 and 1993. The clinical diagnosis of dilated cardiomyopathy was made according to strict criteria as recommended by the World Health Organisation and the National Heart, Lung and Blood Institute. ${ }^{218}$ All patients over the age of 40 , and any $\leqslant 40$ years with a history suggestive of ischaemic heart disease or electrocardiographic evidence of exertional ischaemia, had selective coronary angiography and left ventriculography. Right ventricular endomyocardial biopsy was performed in 79 patients, and was assessed by light microscopy using the Dallas criteria. ${ }^{19}$ Twenty nine patients (24\%) who had a history of chronic excess alcohol consumption ( $>8$ units per day for males and $>6$ units per day for females) were included in the study. Besides invasive assessment patients were evaluated with cross sectional echocardiography and maximum oxygen consumption $\left(\mathrm{V} \mathrm{O}_{2 \max }\right)$ exercise tests. Twenty one $(17 \%)$ patients were taking digoxin, 25 $(20 \%)$ received amiodarone, $104(84 \%)$ vasodilator drugs, and all patients were prescribed diuretic drugs. Serum from the time of diagnosis was unavailable from 21 index cases whose relatives were included in the family study. 


\section{RELATIVES OF PATIENTS WITH DILATED} CARDIOMYOPATHY

Two hundred and fifty two relatives (age 35 (SD 17) years, 126 male, 126 female) from 53 of the 123 index cases included in the study were identified by prospective family screening. The remaining 70 pedigrees were not screened because the pedigree was small $(<2$ available first degree relatives), parenthood was uncertain, large numbers of relatives lived abroad, or the relatives declined screening. Familial dilated cardiomyopathy was defined as the presence of at least one first or second degree relative with documented dilated cardiomyopathy during life or at necropsy examination. All relatives were assessed with physical examination, resting 12 lead electrocardiography, cross sectional echocardiography, and metabolic exercise testing with measurement of $\mathrm{VO}_{2 \max } \cdot \mathrm{VO}_{2 \max }$ measurements were corrected for age and body surface area according to a standard formula. ${ }^{20}$ Echocardiograms were performed and measured by a single experienced echocardiographer. Left ventricular measurements were obtained at the level of the mitral valve in the short axis view using $M$ mode recordings. In order to assess the prevalence of early disease in relatives, values for left ventricular end diastolic diameter were corrected for age and body surface area, using a standard formula to obtain the percentage predicted left ventricular end diastolic diameter ${ }^{21}$; left ventricular enlargement was defined as a left ventricular end diastolic diameter $>112 \%$ of predicted, in the absence of systemic arterial hypertension or other recognised causes. Fractional shortening was defined as abnormal if it was $\leqslant 25 \%$. Relatives that had both left ventricular enlargement and depressed fractional shortening were classified as potentially affected.

\section{PATIENTS WITH ISCHAEMIC HEART DISEASE} AND NORMAL CONTROLS

The ischaemic heart disease control group included 92 consecutive patients (age 63 (SD 11) years, 65 male, 27 female), admitted to the coronary care unit with unstable angina. This was defined as chest pain at rest of $>10$ min duration within $12 \mathrm{~h}$ of admission to hospital, associated with reversible ST or T wave segment changes on electrocardiogram; all patients underwent coronary angiography and left ventriculography and sera was obtained within $3 \mathrm{~h}$ of admission. Forty five (49\%) of the patients with ischaemic heart disease had a previous $Q$ wave myocardial infarction and 37 $(40 \%)$ had poor left ventricular function (ejection fraction $<30 \%$ ). Thirty six patients (33\%) had a documented history of systemic hypertension (defined as blood pressure > $150 / 90 \mathrm{~mm} \mathrm{Hg})$. Seven patients $(12 \cdot 5 \%)$ had previous coronary angioplasty and another 12 (13\%) had previously undergone coronary artery bypass surgery. Cardiac catheterisation revealed multivessel disease in $74(80 \%)$ and single vessel disease in the remainder.

The normal control population consisted of 203 healthy blood donors, aged 45 (SD 16) years, 100 male, 103 female.

\section{IMMUNOLOGICAL METHODS}

\section{Preparation of antigen}

Atrial tissue was obtained from one normal donor heart at the time of transplantation. Histological examination of tissue excluded specific heart muscle disease, inflammation, and necrosis. Samples used for myosin preparation were frozen in liquid nitrogen and stored at $-80^{\circ} \mathrm{C}$ until used. Myosin samples were prepared as previously described. ${ }^{1422}$ All solutions contained a number of proteolytic inhibitors, in particular $5 \mathrm{mM}$ EGTA, $3 \mathrm{mM}$ benzamidine, and $10 \mathrm{mM}$ phenylmethyl-sulphonyl-fluoride. Samples were homogenised and washed four times with 40 $\mathrm{mM} \mathrm{KCl}$ at $4^{\circ} \mathrm{C}$. Extracting solution containing $300 \mathrm{mM} \mathrm{KCl}, 0.1 \mathrm{mM}$ dithiothreitol, 150 $\mathrm{mM}$ phosphate buffer, and $5 \mathrm{mM} \mathrm{MgATP}$ at $\mathrm{pH} 6.5$ was added $(20 \mathrm{ml}$ for each gram of tissue). After $30 \mathrm{~min}$, the insoluble residues were removed from the extract by centrifugation at $27000 \mathrm{~g}$ for $15 \mathrm{~min}$. The supernatant was further centrifuged at $150000 \mathrm{~g}$ for $2 \mathrm{~h}$, and subsequently dialysed overnight against $30-40$ volumes of a solution containing $10 \mathrm{mM} \mathrm{KCl}$, $0.1 \mathrm{mM}$ dithiothreitol, and $1 \mathrm{mM}$ Tris- $\mathrm{HCl}$ at pH 7.2. Precipitated $\alpha$ myosin was collected by low speed centrifugation and resuspended in $0.5 \mathrm{M} \mathrm{NaCl}-50 \%$ glycerol.

Western blot overlay studies, performed as previously described, ${ }^{14}$ showed that there was contamination of the purified atrial myosin with small amounts of IgG. This was removed with affinity chromatography. The $\alpha$ myosin sample at a concentration of approximately $0.5 \mathrm{mg} / \mathrm{ml}$ was passed down a $2 \mathrm{ml}$ column (Pierce) packed with an agarose gel containing beads linked to anti-human IgG (Sigma). The binding equivalent of this gel was $1 \mathrm{mg}$ of human IgG per ml of resin. Myosin was diluted in $\mathrm{pH} \mathrm{9.6} \mathrm{carbonate-bicarbonate}$ buffer containing $50 \mathrm{mmol}$ sodium pyrophosphate to enhance solubility. Protein concentration was determined according to the bicinchoninic acid method (Pierce).

\section{Immunosorbent assay method}

Ninety six well enzyme linked immunosorbent assay plates (Immulon 1; Dynatech) were coated with sequential duplicates of $100 \mu \mathrm{l}$ purified human atrial myosin at a concentration of $5 \mu \mathrm{g} / \mathrm{ml}$. Control wells contained buffer alone. Plates were incubated for $1 \mathrm{~h}$ at $37^{\circ} \mathrm{C}$ with shaking and washed six times with phosphate buffered saline (PBS) solution (Sigma) containing $0.1 \%$ Tween 20 (PBS-T). All wash steps between incubations were identical. Wells were blocked with $200 \mu$ l PBS-T containing $2 \%$ bovine serum albumin fraction $\mathrm{V}$ (Sigma), then incubated for $30 \mathrm{~min}$ at $37^{\circ} \mathrm{C}$ with shaking, and washed. Wells were next coated with $100 \mu \mathrm{l}$ duplicates of each serum sample. These were diluted at $1 / 40$ and $1 / 320$ in PBS-T containing $1 \%$ phosphate buffered saline, and had previously been centrifuged at $10000 \mathrm{rpm}$ for $2 \mathrm{~min}$. Serum samples from patients and controls were analysed in a "blinded" fashion by the same operator. Each plate in each assay contained a positive control serum sample from the same dilated cardio- 
myopathy patient, who showed consistently high responses. The layout of each plate included four blank wells that contained medium alone. Plates were incubated for $1 \mathrm{~h}$ at $37^{\circ} \mathrm{C}$ with shaking and then washed. Wells were then coated with $100 \mu \mathrm{l}$ of biotinylated goat anti-human IgG $\gamma$ chain (Vector Laboratories) diluted $1 / 1000$ in PBS-T, incubated for $1 \mathrm{~h}$ at $37^{\circ} \mathrm{C}$ with shaking, and washed. Avidin-peroxidase complex solution (Vector Laboratories) was prepared according to the manufacturers' instructions by dilution in PBS-T $1 \mathrm{~h}$ before use, and stored at $4^{\circ} \mathrm{C}$, $100 \mu \mathrm{l}$ of avidin-peroxidase complex was added to each well, and plates were incubated for $1 \mathrm{~h}$ at $37^{\circ} \mathrm{C}$ with shaking, and washed. Finally, plates were coated with $100 \mu \mathrm{l}$ of orthophenyl diamene substrate (Sigma) and incubated for $15 \mathrm{~min}$ at $37^{\circ} \mathrm{C}$ in the dark without agitation; absorbance was assessed immediately using a Pasteur Diagnostics Enzyme Linked Immunosorbent Assay reader at 450 $\mathrm{nm}$, linked to Arcom Macintosh software.

\section{Calculation of Enzyme Linked Immunosorbent} Assay results

The mean absorbance obtained from the "blank" wells on each plate was subtracted from the values for each serum sample both in the presence and absence of myosin. The value achieved in absence of myosin was then subtracted from that obtained in presence of myosin to provide the true absorbance attributable to that serum sample. The value of the positive control for each plate was adjusted to an absorbance of 1.0 to provide a correction ratio that was then applied to all the other samples on the plate.

STATISTICAL ANALYSIS

$\chi^{2}$ Analysis, analysis of variance, or unpaired two tailed Student's $t$ tests were used as appropriate. A probability of $<0.05$ was considered

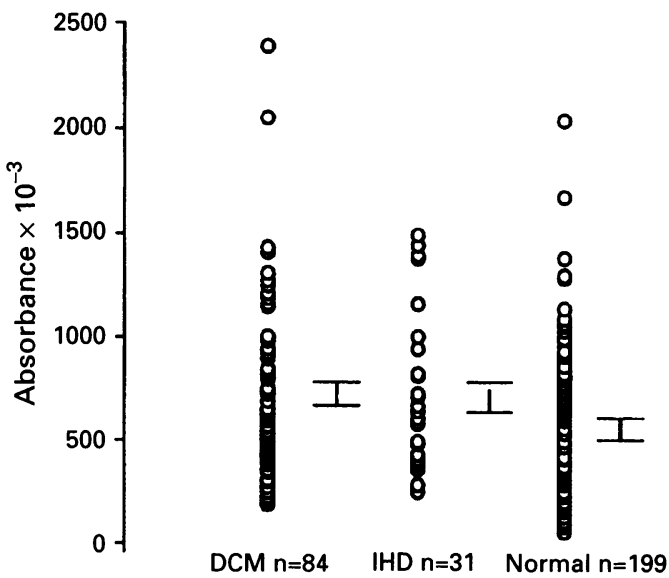

Figure 1 Comparison of anti-a-myosin antibody in patients with dilated cardiomyopathy, ischaemic heart patients with dilated cardiomyopathy, ischaemic heart raised anti-a-myosin antibody levels (serum dilution 1/40) in patients with dilated cardiomyopathy $(n=81)$ compared to normal controls $(n=199)$, but not to ischaemic heart disease patients $(n=31)$ at serum dilution $1 / 40$, suggesting that anti-a-myosin antibodies are not specific for dilated cardiomyopathy at this serum dilution. DCM, idiopathic dilated cardiomyopathy; IHD, ischaemic heart disease. $D C M$ v IHD, NS; DCM v normal, $P=0.003 ; I H D$ v normal, $P=0.008$ to be statistically significant. All antibody levels are expressed as mean absorbance at 450 $\mathrm{nm}$ with SEM in parentheses. The upper limit of normal for the assay was defined as $2 \mathrm{SD}$ deviations above the mean value obtained from normal controls, and all values greater than this cutoff were defined as abnormal antibody levels.

\section{Results}

CLINICAL CHARACTERISATION OF PATIENTS WITH DILATED CARDIOMYOPATHY AND THEIR RELATIVES

Seventy four patients were in New York Heart Association (NYHA) functional class I/II and 49 were in class III/IV. Patients had been symptomatic for 35 (SD 49) months (range 0-204) before diagnosis, and $71(59 \%)$ were clinically deteriorating, defined as a change in NYHA status from I/II to III/IV in the six months before diagnosis; the mean $\mathrm{VO}_{2 \max }$ was 21 (SD 10) $\mathrm{ml} / \mathrm{min} / \mathrm{kg}$. Cross sectional echocardiography showed a mean left ventricular diastolic diameter of $70(11) \mathrm{mm}$ and fractional shortening of $15(8) \%$. Left ventriculography revealed a mean ejection fraction of $24(11) \%$; pulmonary capillary wedge pressure was $21(9) \mathrm{mm} \mathrm{Hg}$. At endomyocardial biopsy 51 patients $(65 \%)$ had established endomyocardial fibrosis compatible with dilated cardiomyopathy; the remainder had normal histology.

All relatives were asymptomatic and had normal 12-lead resting electrocardiograms. The mean $\mathrm{VO}_{2 \max }$ was $40(10) \mathrm{ml} / \mathrm{min} / \mathrm{kg}$. In 35 relatives $(14 \%)$ left ventricular function was considered normal but the quality of the echocardiographic recording was unsatisfactory for quantitative measurements. Echocardiographic assessment revealed a mean left ventricular diastolic diameter of 50 (6) $\mathrm{mm}$, left ventricular systolic diameter of 33 (6) $\mathrm{mm}$, and fractional shortening of 33 (6)\%. Left ventricular enlargement was identified in $36(17 \%)$ relatives, depressed fractional shortening in only $9(4 \%)$, and $17(7 \%)$ had both left ventricular enlargement and depressed fractional shortening. The remaining 190 relatives were echocardiographically normal.

STANDARDISATION OF ENZYME LINKED IMMUNOSORBENT ASSAY

Absolute absorbance recorded in the blank wells was $0 \cdot 05-0 \cdot 07$. The optimal concentration of myosin was found to be $5 \mu \mathrm{g} / \mathrm{ml}$. The detection range of the assay was down to serum dilution of $1 / 640$. Maximum signal was achieved at $1 / 40$ but this dilution did not discriminate between patients with dilated cardiomyopathy and ischaemic heart disease $(0.69(0.04)$ v $0.70(0.07) ; \mathrm{P}=\mathrm{NS})$ (fig 1$)$, although antibody levels were higher in dilated cardiomyopathy patients than in normals $(0.69$ (SEM 0.04) v $0.5(0.02) ; P=0.03)$. Therefore a serum dilution of $1 / 320$ was chosen as appropriate for screening large numbers of sera. Antibody levels at $1 / 320$ correlated with those obtained at $1 / 40 \quad(r=0 \cdot 7$, $P \ll 0.001)$ when considering all results from 
Figure 2 Comparison of anti-a-myosin antibody in patients with dilated cardiomyopathy. The scattergram shows raised anti-a-myosin antibody dilated cardiomyopathy compared to 92 ischaemic heart disease patients and 203 normal controls at serum dilution $1 / 320$. DCM, idiopathic dilated cardiomyopathy; IHD, Dashed line represents cutoff for normal. $D C M$ v $I H D, P=0.001$ $D C M$ v normal, $P=0.0001 ;$ IHD v normal, $P=N S$. levels in 123 patients with ischaemic heart disease.

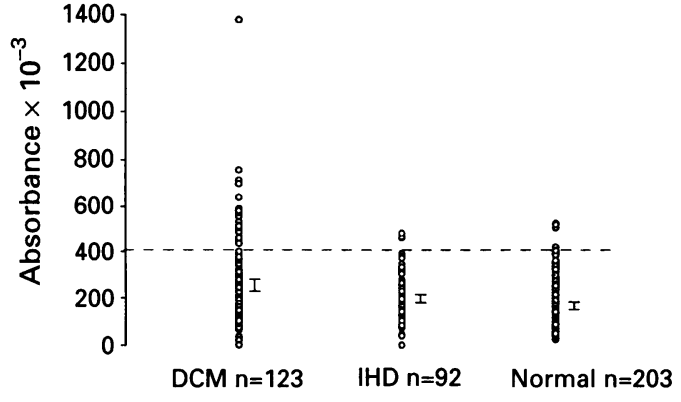

patients with dilated cardiomyopathy or ischaemic heart disease, relatives, and normal controls; this association was even stronger in the patients alone $(r=0.8, P \ll 0.001)$. To assess interassay variation, sera were randomly chosen from 30 patients, and measured twice in separate assays on different days (serum dilution of $1 / 320$ ); the correlation between absorbances was $r=0.74(\mathrm{P}<0.001)$.

\section{ANTI- $\alpha$-MYOSIN ANTIBODY IN PATIENTS WITH DILATED CARDIOMYOPATHY}

Patients with dilated cardiomyopathy had higher antibody levels than patients with ischaemic heart disease $(0.27$ (SEM 0.02) $v$ $0.20(0.01), P=0.001)$ or normal individuals $(0.27$ (SEM 0.02) $v 0.17(0.01), \mathrm{P}=0.001)$, and there was no significant difference between ischaemic heart disease and controls (fig 2). A greater proportion of patients with dilated cardiomyopathy $(25 / 123,20 \%)$ had an abnormal result compared to patients with ischaemic heart disease $(4 / 92,4 \%, P=0.001)$ and normal controls $(4 / 203,2 \%, P \ll 0 \cdot 001)$. The frequency of abnormal antibody results was similar in ischaemic heart disease and normals (4/92, $4 \% v 4 / 203,2 \%, P=N S)$.

Prevalence of anti-a-myosin antibodies in pedigrees

\begin{tabular}{lccc}
\hline ELISA & Familial & Non-familial & $P$ \\
\hline \multicolumn{4}{c}{ Patients with dilated cardiomyopathy $(n=32)$} \\
Abnormal, n (\%) & $1(9)$ & $6(29)$ & NS \\
Normal, n (\%) & $10(91)$ & $15(71)$ & \\
\multicolumn{5}{c}{ Relatives of patients with dilated cardiomyopathy } & $(n=252)$ \\
Abnormal, n (\%) & $8(8)$ & $33(21)$ & 0.005 \\
Normal, n (\%) & $90(92)$ & $121(79)$ & \\
\hline
\end{tabular}

ELISA, enzyme linked immunosorbent assay

^ELISA was not performed in six patients with dilated cardiomyopathy with familial and 15 with non-familial disease.

Figure 3 Comparison of anti-a-myosin antibody in relatives of patients with dilated cardiomyopathy.

The scattergram shows raised anti-a-myosin antibody levels in 252 relatives of 53 patients with dilated

cardiomyopathy compared to normal controls ( $n=$ 203) at serum dilution $1 / 320$.

Relatives $v$ normals, $P<0.001$.
Although an abnormal antibody result tended to be more common in patients with non-familial dilated cardiomyopathy than in those with familial disease, this difference was not statistically significant $(6 / 21,29 \% v 1 / 11$, $9 \% ; P=N S)$. In the remaining 21 index cases whose pedigrees were screened, serum from the time of diagnosis was not available (table).

ANTI- $\alpha$-MYOSIN ANTIBODY IN RELATIVES OF PATIENTS WITH DILATED CARDIOMYOPATHY Mean antibody levels were greater in relatives than in controls $(0.26(0.01) v 0.17(0.01)$; $P \ll 0.001$ ) (fig 3 ); a greater proportion of relatives had an abnormal result compared to normal controls $(41 / 252,16 \% v 4 / 203,2 \%$; $P \ll 0.001)$.

In the 16 pedigrees with familial disease the proportion of relatives with an abnormal antibody level was lower $(8 \%)$ than that observed in non-familial pedigrees $(21 \%, P=0.005)$ (table) but still greater than that in the normal control population $(2 \%, \mathrm{P}=0.02)$. Relatives from kindreds with familial dilated cardiomyopathy had lower antibody levels than those with non-familial dilated cardiomyopathy $(0.21$ (SEM 0.01) v 0.29 (0.01); $\mathrm{P} \ll 0.001)$.

The relation between antibody status of relatives from the 53 pedigrees and their index case is shown in fig 4 . The anti-myosin antibody was present in $20 / 53(38 \%)$ of the pedigrees. Three of seven pedigrees $(43 \%)$ whose proband result was abnormal had $\geqslant 1$ relative who also had an abnormal result compared to seven of 25 pedigrees $(28 \%)$ whose proband antibody status was normal $(P=N S)$. Higher antibody levels were identified in 53 relatives for whom the proband had an abnormal antibody result compared to 116 relatives for whom the proband had a normal antibody result $(0.37(0.02) v 0.22(0.01) ; \mathrm{P} \ll 0.001)$.

\section{CORRELATION OF ANTIBODY STATUS WITH} CLINICAL DATA IN PROBANDS AND RELATIVES There was no relationship between antimyosin antibody levels and the clinical features (including alcohol consumption), or haemodynamic, echocardiographic, and exercise measurements in the probands with dilated cardiomyopathy. Anti-myosin antibody levels were not associated with any of the medications taken by the patients.

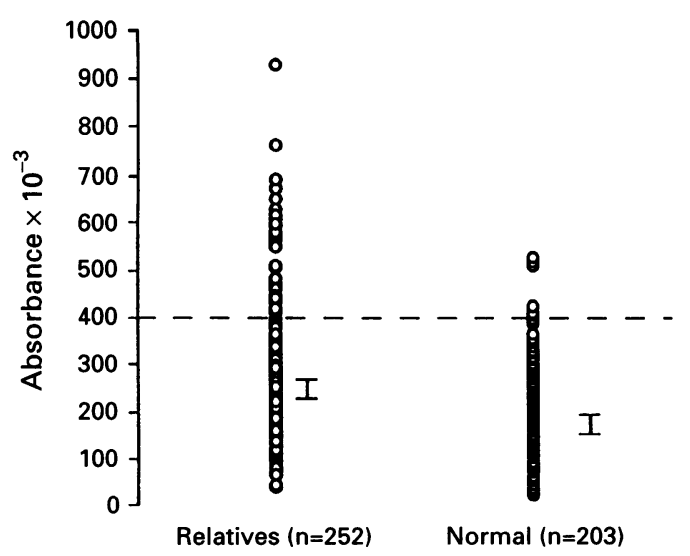

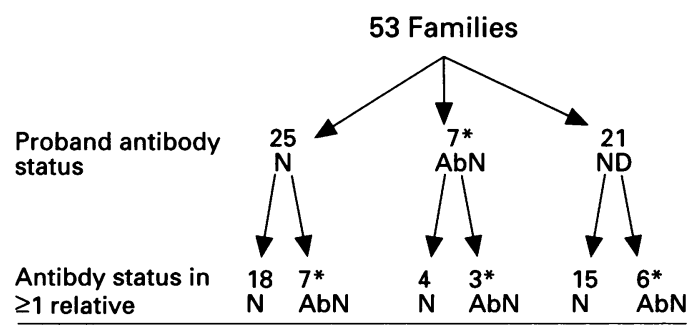

*Pedigrees with positive autoimmune serology for $\alpha$ myosin

Figure 4 Relation between anti-a-myosin antibody status of proband with dilated cardiomyopathy and relatives. The figure describes the association between anti-a-myosin antibody status of relatives from 52 pedigrees $(n=252)$ and probands with dilated cardiomyopathy $(n=32)$. $N$, normal; AbN, abnormal; ND, not done. 
Among the relatives, females had higher anti- $\alpha$-myosin antibody levels than males $(0 \cdot 28$ (SEM 0.01) v 0.23 (0.01), $\mathbf{P}=0.03)$. Similar proportions of abnormal antibody results were found in relatives classified as normal, left ventricular enlargement, or potentially affected on the basis of established echocardiographic cutoffs $(30 / 158,30 \% ; 3 / 36,8 \% ; 1 / 17,16 \%$ respectively; $\mathrm{P}=\mathrm{NS}$ ). Relatives with left ventricular enlargement had lower antibody levels than those with normal echocardiograms $(0 \cdot 21$ $(\operatorname{SEM} 0.02) v 0.27(0.01) ; \mathrm{P}=0.03)$.

\section{Discussion}

Enzyme immunosorbent assay (ELISA) has not previously been used to detect antibodies to cardiac specific human $a$ myosin in dilated cardiomyopathy. ${ }^{16} \mathrm{~A}$ recent report found that $20 \%$ of patients with dilated cardiomyopathy possessed raised antibodies to human $\beta$ myosin (cross reactive with skeletal muscle), but did not state the prevalence of this antibody in ischaemic heart failure controls. ${ }^{17}$ Lauer et al identified low titre (1/40) antibodies to human $\beta$ myosin in $42 \%$ of patients with acute myocarditis and in $21 \%$ of a heterogeneous group of cardiac patients who mainly had coronary disease. ${ }^{16}$ A separate study of ischaemic heart disease patients used rabbit $\beta$ myosin to detect anti-myosin antibodies in $38 \%$ of patients after cardiac surgery and in $16 \%$ following myocardial infarction, but neither the titre of serum used nor the cutoff for positivity was reported. ${ }^{2324}$ A similarly high proportion of cross-reactive antibodies has already been documented in ischaemic heart disease controls using an immunofluorescent technique. ${ }^{5}$ Conversely, the low prevalence in the present study of antibodies to a myosin among patients with ischaemic heart disease indicates that these markers are more specific for dilated cardiomyopathy. Thus previous studies have either examined cross-reactive $\beta$ myosin or myosin of animal origin, or have not compared antibody levels with patients with ischaemic heart disease. In addition to the lack of disease specificity, ELISA studies using myosin of animal origin ${ }^{23} 24$ have the limitation that the antigenic epitopes recognised by human sera may not occur in myosin proteins from different species, and the prevalence of antibodies against tissue specific human $\beta$ myosin (present in skeletal muscle) has not been assessed.

In this study a standardised ELISA showed that $20 \%$ of patients with dilated cardiomyopathy, $16 \%$ of their relatives, and $38 \%$ of dilated cardiomyopathy families possess high titre organ and disease specific anti- $a$-human myosin antibodies. The finding of disease specific antibodies to $a$ myosin in this patient population confirms previous studies using western blotting, ${ }^{1415}$ and also suggests that the antigenic specificity of antibodies detected by indirect immunofluorescence in $25 \%$ of the same cohort of relatives include $a$ myosin. ${ }^{10}$

Our findings of increased anti- $a$-myosin antibody in patients with dilated cardiomyo- pathy and their relatives are also relevant because $a$ myosin is the only autoantigen that fulfils the criteria for organ specific autoimmunity, ${ }^{25}$ in that immunisation of susceptible mice with cardiac $(a)$, but not skeletal myosin $(\beta)$, reproduced the human disease phenotype. ${ }^{12}$ This suggested that the pathogenically important autoimmune epitopes reside on the $a$ isoform, which is not expressed in murine or human skeletal muscle.

Antibody concentrations in symptom-free relatives were higher than in normal controls and were higher in relatives of index cases who had an abnormal result compared to relatives of probands who had a normal result, suggesting that antibody responses to $a$ myosin tend to segregate in specific pedigrees. Moreover, lower mean antibody concentrations were present in relatives of kindreds with familial disease than in relatives from non-familial pedigrees. A previous report found that antiheart antibodies against a range of antigens were more common in relatives from pedigrees with familial disease, and also documented an association between the presence of antibodies and ventricular dimensions; $;^{10}$ the detection of responses to antigens other than $a$ myosin may explain the apparent discrepancy. In this study we used a higher serum dilution (1/320) than that employed in indirect immunofluorescence and examined humoral responses to $\alpha$ myosin alone, but apart from the finding of higher anti- $a$-myosin antibody levels in female relatives we did not detect any association with clinical variables. Although the mean level of antibody was lower in asymptomatic relatives with left ventricular enlargement than in those with normal echocardiograms, the prevalence of abnormal antibody results was similar in the two groups.

The prevalence of antibodies tended to be higher in those patients with non-familial disease $(29 \%)$ than those with familial disease $(9 \%)$, in whom genetic mechanisms of pathogenesis might predominate, but this difference was not statistically significant. Similarly, Michels et al found no association between familial disease and the prevalence of antibodies to human ventricular myosin in patients with dilated cardiomyopathy. ${ }^{17}$ In order to enhance the specificity of an abnormal anti- $a$ myosin antibody result for dilated cardiomyopathy in the present study, a high serum dilution was employed (1/320). Consequently the number of patients with abnormal results was reduced, and this may have limited the statistical power of the study to detect relations with clinical variables.

The fact that anti- $a$-myosin antibodies were present in only a minority of pedigrees (38\%) emphasises the heterogeneity of aetiologies in dilated cardiomyopathy, and suggests that immune responses to $a$ myosin are present only in a subset of individuals. Cardiac antigens other than myosin may, however, also be important in the pathogenesis of dilated cardiomyopathy: western blot studies have shown that $\alpha$ myosin is only one of several antigens recognised by sera from patients, and the total proportion of dilated cardiomyopathy patients 
with immune abnormalities could be higher than that reported in this study. ${ }^{14} 15$

The presence of raised concentrations of anti- $\alpha$-myosin antibodies in dilated cardiomyopathy pedigrees with both familial and nonfamilial disease does not support a primary pathogenic role for this antibody ${ }^{26}$; the antibody is more likely to be a marker of disease predisposition. The ability of an abnormal ELISA result to predict future disease in asymptomatic relatives will only be clarified by longitudinal study, although its use in screening will be limited by the sensitivity of the assay.

In conclusion, the description of antibodies to $\alpha$ myosin in patients and their relatives provides another clue for a role for autoimmunity in the pathogenesis of dilated cardiomyopathy, and emphasises the importance of $a$ myosin as a potential target antigen in selected patients with this disease. We acknowledge the support and advice of Professor F Hay,
Dr Andrew Soltys, Dr David Rees, and Mrs Azita Alavi of the Dr Andrew Soltys, Dr David Rees, and Mrs Azita Alavi of the School. We would like to thank Mr Gobbo for technical assisSchool. We would like to thank $\mathrm{Mr}$ Gobbo for technical assis-
tance in preparation of antigen. JHG, PJK, KB, and SR were tance in preparation of antigen. JHG, PJK, KB, and SR were
supported by grants from the British Heart Foundation, and supported by grants from the British Heart Foundation, and ALPC by grants from the Veneto region target project on carproject "FAT.MA" (Rome, Italy).

1 Goodwin JF, Oakley CM. The cardiomyopathies. $\mathrm{Br} \mathrm{Heart} \mathcal{F}$ $1972 ; 34: 545-52$.

2 Manolio TA, Baughman KL, Rodeheffer $\mathrm{R}$, et al. Prevalence and etiology of idiopathic dilated cardiomyopathy. Am $₹$ Cardiol 1992;69:1458-66.

3 Mestroni L, Miani D, Di LA, et al. Clinical and pathologic study of familial dilated cardiomyopathy. Am $\mathcal{f}$ Cardiol 1990;65:1449-53.

4 Michels VV, Moll PP, Miller FA, et al. The frequency of familial dilated cardiomyopathy in a series of patients with idiopathic dilated cardiomyopathy. $N \mathrm{Engl} f \mathrm{Med}$ 1992;326:77-82.

5 Caforio AL, Bonifacio E, Stewart JT, et al. Novel organspecific circulating cardiac autoantibodies in dilated cardiomyopathy. F Am Coll Cardiol 1990;15:1527-34.

6 Neumann DA, Burek CL, Baughman KL, Rose NR, Herskowitz A. Circulating heart-reactive antibodies in patients with myocarditis or cardiomyopathy. $7 \mathrm{Am}$ Coll Cardiol 1990;16:839-46.

7 Schultheiss HP, Schultze K, Huhl U, Ulrich G Klingenberg $M$. The ADP/ATP carrier as a mitochondrial autoantigen-facts and perspectives. Ann NY Acad Sci autoantigen-facts

8 Limas CJ, Goldenberg IF, Limas C. Autoantibodies against beta-adrenoceptors in human idiopathic dilated cardiomyopathy. Circ Res 1989;64:97-103.

9 Carlquist JF, Menlove RL Murray MB, O'Connell JB Anderson JL. HLA class II (DR and DQ) antigen associations in idiopathic dilated cardiomyopathy. Validation study and meta-analysis of published HLA association studies. Circulation 1991;83:515-22.

10 Caforio ALP, Keeling PJ, Zachara E, et al. Evidence from Family Studies for Autoimmunity in Dilated Cardiomyopathy. Lancet 1994;344:773-7.

11 Neu N, Beisel KW, Traystman MD, Rose NR, Craig SW. Autoantibodies specific for the cardiac myosin isoform are found in mice susceptible to Coxsackievirus B3induced myocarditis. F Immunol 1987;138:2488-92.

12 Neu N, Rose NR, Beisel KW, Herskowitz A, Gurri GG, Craig SW. Cardiac myosin induces myocarditis in genetically predisposed mice. F Immunol 1987;139:3630-6.

13 Bouvagnet P, Mairhofer H, Leger JO, Puech P, Leger JJ. Distribution pattern of alpha and beta myosin in normal Distribution pattern of alpha and beta myosin in normal
and diseased human ventricular myocardium. Basic Res and diseased human ventr.

14 Caforio AL, Grazzini M, Mann JM, et al. Identification of alpha- and beta-cardiac myosin heavy chain isoforms as major autoantigens in dilated cardiomyopathy. Circulation 1992;85:1734-42.

15 Latif N, Baker CS, Dunn MJ, Rose ML, Brady P, Yacoub MH. Frequency and specificity of antiheart antibodies in patients with dilated cardiomyopathy detected using SDS-PAGE and western blotting. I Am Coll Cardiol 1993;22:1378-84.

16 Lauer B, Padberg K, Schultheiss HP, Strauer BE. Autoantibodies against human ventricular myosin in sera of patients with acute and chronic myocarditis. $\mathcal{f} \mathrm{Am} \mathrm{Coll}$ Cardiol 1994;23:146-53.

17 Michels VV, Moll PP, Rodeheffer RJ, et al. Circulating heart autoantibodies in familial as compared with nonfamilial idiopathic dilated cardiomyopathy. Mayo Clin Proc 1994;69:24-7.

18 Brandenberg RO, Chazov E, Cherian G, et al. Report of the WHO/ISFC task force on definition and classification of the cardiomyopathies [abstr]. Circulation 1981;64: 437-8A.

19 Aretz H, Billingham M, Edwards W, et al. Myocarditis, a histopathologic definition and classification. $A m \mathcal{F}$ Cardiovasc Pathol 1987;1:3-14.

20 Blackie SP, Fairbarn MS, McElvaney GN, Morrison NJ, Wilcox PG, Pardy RL. Prediction of maximal oxygen uptake and power during cycle ergometry in subjects older than 55 years of age. Am Rev Respir Dis 1989; 139:1424-9.

21 Henry WL, Gardin JM, Ware JH. Echocardiographic measurements in normal subjects from infancy to old age. surements in normal subjects
Circulation 1980;62:1054-61.

22 Dalla Libera L, Margreth A, Mussini I, Cerri C, Scarlato G. Myosin polymorphism in human skeletal muscle. Muscle Nerve 1978;1:280-91.

23 De Scheerder IK, Vandekerckove J, Robbrecht J, et al. Post-cardiac injury syndrome and an increased humoral immune response against the major contractile proteins (actin and myosin). Am F Cardiol 1985;56:631-3.

24 De Scheerder IK, De Buyzere M, De Langhe J, Maas A, Clement DL, Wieme R. Humoral immune response against contractile proteins (actin and myosin) during cardiovascular disease. Eur Heart $\mathcal{f}$ 1991;12:88-94.

25 Rose NR, Bona C. Defining criteria for autoimmune diseases (Witebsky's postulates revisited). Immunol Today 1991;14:426-8.

26 Herskowitz A, Neumann DA, Ansari AA. Concepts of autoimmunity applied to dilated cardiomyopathy. $\mathcal{F} \mathrm{Am}$ Coll Cardiol 1993;22:1385-8. 
1 Lip GYH, Tean KN, Dunn FG. Treatment of atrial fibrillation in a district general hospital. Br Heart $\mathcal{f} 1994 ; 71$ : 92-5.

2 Bath PMW, Prasad A, Brown MM, MacGregor GA Survey of use of anticoagulation in patients with atrial fibrillation. $B M \mathcal{F}$ 1993;307:1045.

3 Hendry A, Campbell AM, Campbell G, Macdonald JB, Williams BO. Antithrombotic therapy prescribed fo patients with non-rheumatic atrial fibrillation. Scott Med f 1994;39:110-1.

4 Chang HJ, Bell JR, Deroo DB, Kirk JW, Wasson JH Physician variation in anticoagulating patients with atrial fibrillation. Arch Intern Med 1990;150:83-6.

5 Lowe GDO. Antithrombotic treatment and atrial fibrillation. $B M \mp$ 1992;305:1445-6.

6 Atrial fibrillation investigators. Risk factors for stroke and efficacy of antithrombotic therapy in atrial fibrillation. Analysis of pooled data from five randomised controlled trials. Arch Intern Med 1994;154:1449-57.

7 Stroke prevention in atrial fibrillation investigators. Warfarin versus aspirin for prevention of thromboembolism in atrial fibrillation: stroke prevention in atrial fibrillation II study. Lancet 1994;343:687-91.

8 Brook RH, Park RE, Winslow CM, Kosecoff JB, Chassin MR, Hampton JR. Diagnosis and treatment of coronary disease: comparison of doctors' attitudes in the USA and dise UK. Lancet 1988;i:750-3.

9 Stroke prevention in atrial fibrillation investigators Predictors of thromboembolism in atrial fibrillation: $I$ Clinical features of patients at risk. Ann Intern Med 1992 116:1-5

10 Stroke prevention in atrial fibrillation investigators Predictors of thromboembolism in atrial fibrillation: II. Echocardiographic features of patients at risk. Ann Intern Med 1992;116:6-12.

11 Petersen P. Thromboembolic complications in atrial fibrillation. Stroke 1990;21:4-13.

12 Petersen P. Thromboembolic complications of atrial fibrillation and their prevention: a review. Am f Cardiol 1990; 65:24-28C

13 Selzer A. Atrial fibrillation revisited. $N$ Engl f Med 1982;
306:1044-5

14 Sobel BE. Thrombolysis in the treatment of acute myocardial infarction. In: Fuster V, Verstraete M, ed. Thrombosis in cardiovascular disorders. Philadelphia: WB Saunders, 1992:289-326.

15 Turpie AGG, Robinson JH, Doule DJ, et al. Comparison of high dose with low-dose subcutaneous heparin to prevent left ventricular mural thrombosis in patients with acute transmural anterior myocardial infarction. $N$ Engl $\mathcal{F}$ Med 1989;320:352-7.

16 Alpert JS, Petersen P, Godtfredsen J. Atrial fibrillation: natural history, complications, and management. Annu Rev Med 1988;39:41-52.

17 Dittrich HC, Erickson JS, Schneidermen T, Blacky AR Savides T, Nicod PH. Echocardiographic and clinical predictors for outcome of elective cardioversion of atrial fibrillation. Am 7 Cardiol 1989;63:193-7.

18 ACP/ACC/AHA Task Force Statement. Clinical competence in elective direct current (DC) cardioversion. $\mathcal{f} \mathrm{Am}$ Coll Cardiol 1993;22:336-9.

19 O’Neill PG, Puleo PR, Bolli R, Rokey R. Return of atrial mechanical function following electrical cardioversion of mechanical function following electrical cardio

20 atrial arrhythmias. Am Heart f 1990;120:353-9. PC, Doherty RM, et al. Impaired left atrial mechanical PC, Doherty RM, et al. Impaired left atrial mechanical function after cardioversion: relation to the duration

21 Dunn $M$, Alexander J, de Silva R, Hildner $F$. Antithrombotic therapy in atrial fibrillation. Chest 1989 95:118-27S

22 Kopecky SL, Gersh BJ, McGoon MD, et al. The natura history of lone atrial fibrillation. A population-based study over three decades. $N$ Engl $\mathcal{f}$ Med 1987;317 669-74.

23 Brand FN, Abbott RD, Kannel WB, Wolf PF Characteristics and prognosis of lone atrial fibrillation 30-year follow up in the Framingham study. $7 A M A$ 1985;254:3449-53.

24 Caro JJ, Groome PA, Flegel KM. Atrial fibrillation and anticoagulation: from randomised trials to practice. Lancet 1993;341:1381-4.

\section{CORRECTION}

Autoimmunity to $a$ myosin in a subset of patients with idiopathic dilated cardiomyopathy

f $H$ Goldman, $P \mathcal{F}$ Keeling, $R S$ Warraich, $M K$ Baig, $S R$ Redwood, L Dalla Libera, $\mathcal{F} E$ Sanderson, A L P Caforio, Wf McKenna (Br Heart f 1995;74:598-603).

No institutional affiliation was given for $R S$ Warraich one of the authors of this paper. Her name should have been listed under Department of Cardiological Sciences, St George's Hospital, London.

\section{NOTICE}

The 1996 Annual General Meeting of the British Cardiac Society will take place at the Scottish Exhibition \& Conference Centre, Glasgow from 7 to 9 May. 